\title{
The distribution of a transposase sequence in Moniliophthora perniciosa confirms the occurrence of two genotypes in Bahia, Brazil
}

\author{
Mariana D.C. Ignacchiti, Mateus F. Santana, Elza F. Araújo \& Marisa V. Queiroz \\ Departamento de Microbiologia, BIOAGRO, Universidade Federal de Viçosa, 36571-000, Viçosa, MG, Brazil \\ Author for correspondence: Marisa Vieira de Queiroz, e-mail: mvqueiro@ufv.br
}

\begin{abstract}
Transposase sequence analysis is an important technique used to detect the presence of transposable elements in a genome. Putative transposase sequence was analyzed in the genome of the phytopathogenic fungus Moniliophthora perniciosa, the causal agent of witches' broom disease of cocoa. Sequence comparisons of the predicted transposase peptide indicate a close relationship with the transposases from the elements of the Tc1-Mariner superfamily. The analysis of the distribution of transposase sequence was done by means of PCR and Southern blot techniques in different isolates of the fungus belonging to C-, L-, and S-biotypes and collected from various geographical areas. The distribution profile of the putative transposase sequence suggests the presence of polymorphic copies among the isolates from C-biotypes. The total DNA hybridization profile of each isolate was used to calculate genetic distance and group by the UPGMA method. C-biotype isolates colleted from of the Bahia showed two hybridization profiles for the transposase sequence. Thus the two different fingerprinting profiles for transposase sequence reported here by Southern analysis could also be correlated to the presence of two different genotypes in Bahia, Brazil.
\end{abstract}

Key words: Theobroma cacao, biotypes, DDE motif, genetic variability, transposon, Witches' broom.

\section{RESUMO}

Distribuição de uma sequência de transposase confirma a ocorrência de dois genótipos de Moniliophthora perniciosa na Bahia, Brasil

A análise de sequência de transposase é uma técnica importante para descobrir a presença de elementos transponíveis no genoma. Uma sequência potencial de transposase foi analisada no genoma do fitopatógeno Moniliophthora perniciosa, o agente causal da doença vassoura-de-bruxa no cacau. As comparações de sequência do peptídeo predito para a transposase indicam uma relação com transposases de elementos da superfamília Tc1-Mariner. A análise da distribuição desta sequência de transposase foi realizada através das técnicas de PCR e Southern blot nos diferentes isolados, pertencentes aos biótipos C, L, e S, coletados de várias áreas geográficas. O perfil de distribuição da transposase sugere a presença de cópias polimórficas entre os diferentes isolados do biótipo C. O perfil de hibridização do DNA total de cada isolado foi utilizado para o cálculo de distância genética e agrupamento pelo método de UPGMA. Os isolados do biótipo C coletados no estado da Bahia apresentaram dois perfis de hibridização para a sequência de transposase. Os dois diferentes padrões apresentados na análise de Southern podem ser relacionados com a presença de dois genótipos diferentes na Bahia.

Palavras-chave: Theobroma cacao, biótipos, motivo DDE, variabilidade genética, transposon, vassoura-de-bruxa.

\section{INTRODUCTION}

The phytopathogenic fungus Moniliophthora perniciosa (Stahel) Aime \& Phillips-Mora (2006) (Homobasidiomycetes, Agaricales, Tricholomataceae) is the causal agent of Witches' broom disease, the most serious disease affecting cacao (Theobroma cacao L.), responsible for a $50-90 \%$ reduction in its production (Meinhardt et al., 2008). This disease is endemic of the Amazon region, and the first recorded incident in the Bahia state of Brazil was in 1989 (Pereira et al., 1990). According to pathogenicity data, this species is subdivided into four biotypes: (1) $C$-biotype, infecting Theobroma and Herrania species (Sterculiaceae) (Evans, 1978; Bastos et al., 1988); (2) S-biotype, pathogen of Solanaceae (Bastos \& Evans, 1985); (3) L-biotype, a saprophyte that colonizes a variety of substrates (Evans, 1978; Hedger et al., 1987); and (4) H-biotype, which infects the Heteropterys acutifolia (Malpighiaceae) (Resende et al., 2000).

Somatic incompatibility reactions (Hedger et al., 1987; Viana, 2001) and pathogenicity tests (Bastos et al., 1988; Resende et al., 2000; Viana, 2001) indicate the occurrence of genetic variability among the different biotypes of $M$. perniciosa. At the molecular level, the intraspecific variability of $M$. perniciosa was demonstrated by the restriction fragment length polymorphism (RFLP) pattern and sequencing of the intergenic spacer (IGS) region from the rDNA (Arruda et al., 2003a). Characterization by Enterobacterial Repetitive Intergenic Consensus (ERIC) repetitive element sequence-based PCR from different 
The distribution of a transposase sequence in Moniliophthora perniciosa confirms...

isolates of M. perniciosa has also allowed the detection of intraspecific variability and the correlation of this variation with the host and geographic origin of isolates (Arruda et al., 2003b). Rincones et al. (2003, 2006) showed genotypic polymorphisms among different biotypes and among $C$-biotype isolates from different regions of southern Bahia by electrophoretic karyotype and microsatellite analysis. Furthermore, it has been postulated that the genome variability found in homothallic $M$. perniciosa may be due to transposable elements (TEs) and ectopic recombination guided by the numerous copies of these elements found in the genome (Rincones et al., 2003; Mondego et al., 2008).

Transposable elements (TEs) can be defined as sequences of moderately repetitive DNA, characterized by the ability to move in the genome, from one place to another, regardless of the homology between the genomic region where it is inserted and the location to which it is transposed (Daboussi, 1997). TEs are divided into two main classes by their mode of transposition and structural organization. Class I elements, or retroelements, are transposed through an RNA intermediate; the Class II elements, also called DNA transposon, are transposed directly through a DNA form. Subdivisions of Class I and II in subclasses, superfamilies, families and subfamilies are established according to structural characteristics of the element and amino acid sequence of the proteins encoded by genes present in the element (Wicker et al., 2007).

The discovery that TEs are common components of the genome in plants, insects, animals and fungi has made them objects of interest for studies of the effects they may exert on host genomes (Arkhipova et al., 2003, Taylor et al., 2004; Bouvet et al., 2008, Crouch et al., 2008). As the TEs are repeated sequences dispersed throughout the genome and the majority is inactive, they may be used as polymorphism markers. The examination of TE distribution in natural populations provided valuable information concerning epidemiological and phylogenetic analyses (Daboussi \& Capy, 2003). The discriminatory power of TEs in studies of the characterization of population structure and in the analysis of the variability in fungi has been demonstrated in Magnaporthe grisea, a rice pathogen, from the characterization of polymorphism based on TEs and ISSR markers (Chadha \& Gopalakrishna, 2005). Analysis of the fingerprinting using TEs has also assisted in the molecular characterization of the genetic diversity of Fusarium oxysporum f. sp. phaseoli (Zanotti et al., 2005) and tracing and identification of specific strains of $F$. oxysporum $\mathrm{f}$. sp. lactucae (Pasquali et al., 2007).

A significant increase in the knowledge of the genome of M. perniciosa and the investigation of the plantpathogen interaction started with the design of the "Witches' broom Genome" project. The sequences generated by this project were submitted to a local database with restricted access. Searches in this database show that the pathogen has several sequences related to TEs already ascribed to filamentous fungi (for a review, see Mondego et al., 2008).
Because the genome of $M$. perniciosa contains sequences related to TEs, the aim of this study was to investigate the presence and establish the fingerprinting of a sequence that encodes a transposase in TEs of the Tc1-Mariner superfamily in isolates of $M$. perniciosa belonging to different biotypes and collected from various geographic areas. The study of the distribution of this sequence will contribute to the studies of natural populations and the epidemiology of the Witches' broom disease.

\section{MATERIALS AND METHODS}

\section{Microorganism and culture condition}

The C, S and L-biotype isolates of M. perniciosa examined in this study were kindly given by Prof. Dr. Maricília C. C. Arruda from the Federal University of Brasilia, Brasilia, Distrito Federal/Brazil, Prof. Gonçalo A. G. Pereira from the State University of Campinas, Campinas, São Paulo/Brazil, Prof. Dr. Mário Lúcio Vilela de Resende from Federal University of Lavras, Lavras, Minas Gerais/ Brazil, Dr. Alan W. V. Pomella from Almirante Cacau, Itajuipé, Bahia/Brazil and by Prof. Dr. Robert W. Barreto from the Federal University of Viçosa, Viçosa, Minas Gerais/Brazil. The isolates of M. perniciosa were cultivated for 10 days at $27^{\circ} \mathrm{C}$ in Potato-Dextrose-Agar medium (PDA) (Oxoid) enriched with $0.15 \%$ hydrolyzed casein (Sigma-Aldrich), $0.2 \%$ yeast extract (Sigma-Aldrich) and $0.2 \%$ peptone (Difco), $\mathrm{pH} 6.8$. The isolates analyzed are listed in Table 1. All isolates used in this study can be found in a collection maintained by the Laboratório de Genética de Microorganismos of the Federal University of Viçosa, Viçosa, MG/Brazil.

\section{Primer Design}

Based on sequences available in the database of the "Witches' broom Genome" project, primers were designed to amplify a DNA fragment similar to a transposase, referred in this work as the Mico sequence. The specific primers for this sequence were called MiMp1 (5'GGGAGGTTGAAGGTGAGGTT-3') and MiMp2 (5'-AACACAAGAACGGGATCAGC-3'); this pair of primers was used to amplify a $911 \mathrm{bp}$ fragment. For quality control of DNA amplification we used the primer pair ITS1 (5'-GCTAACAAGGTTTCCGTAGG-3') and ITS4 (5'-TCCTCCGCTTATTGATATGC-3'), which amplified the ITS (internal transcribed spacer) region from the rDNA (White et al., 1990). The ITS region from the rDNA were amplified for all the isolates were analyzed (data not shown).

\section{Total DNA extraction and PCR}

The extraction of total DNA was done according to the method of Speacht et al. (1982). The PCR was done in a reaction mixture of $25 \mu \mathrm{L}$, containing 50 ng of total DNA in $1 \mathrm{x}$ thermophilic DNA poly buffer 
M.D.C. Ignacchiti et al.

TABLE 1- Isolates of Moniliophthora perniciosa analyzed

\begin{tabular}{|c|c|c|c|c|}
\hline $\begin{array}{l}\text { Isolate } \\
\text { Number }\end{array}$ & $\begin{array}{c}\text { Collection } \\
\text { identification }\end{array}$ & Biotype & Locality $^{1}$ & Host \\
\hline 1 & Belmonte & $\mathrm{C}$ & Belmonte, BA, Brazil & Theobroma cacao \\
\hline 2 & Ilhéus & $\mathrm{C}$ & Ilhéus, BA, Brazil & Theobroma cacao \\
\hline 3 & FA277 & $\mathrm{C}$ & Itabuna, BA, Brazil & Theobroma cacao \\
\hline 4 & FA317 & $\mathrm{C}$ & Ilhéus, BA, Brazil & Theobroma cacao \\
\hline 5 & FA563 & $\mathrm{C}$ & Ilhéus, BA, Brazil & Theobroma cacao \\
\hline 6 & FA42 & $\mathrm{C}$ & Itajuipe, BA,Brazil & Theobroma cacao \\
\hline 7 & Santo Amaro & $\mathrm{C}$ & Santo Amaro, BA, Brazil & Theobroma cacao \\
\hline 8 & ESJOH1 & $\mathrm{C}$ & Marituba, PA, Brazil & Theobroma cacao \\
\hline 9 & FA551 & $\mathrm{C}$ & Tabatinga, AM, Brazil & Theobroma cacao \\
\hline 10 & DOA100 & $\mathrm{C}$ & BA, Brazil & Theobroma cacao \\
\hline 11 & DOA102 & $\mathrm{C}$ & BA, Brazil & Theobroma cacao \\
\hline 12 & $\mathrm{CP} 02^{3}$ & $\mathrm{C}$ & Itabuna, BA, Brazil & Theobroma cacao \\
\hline 13 & SABA & $\mathrm{C}$ & Santo Amaro, BA, Brazil & Theobroma cacao \\
\hline 14 & LA17 & $\mathrm{L}$ & Pichilinge, RI, Ecuador & Arrabidaea verrucosa \\
\hline 15 & LEP1 & $\mathrm{L}$ & Pichilinge, RI, Ecuador & Arrabidaea verrucosa \\
\hline 16 & SCL4 & $\mathrm{L}$ & San Carlos, NA, Ecuador & Arrabidaea verrucosa \\
\hline 17 & FA609 & $\mathrm{S}$ & Poços de Caldas, MG, Brazil & Solanum sp. \\
\hline 18 & RWB500 & $\mathrm{S}$ & Rio Pomba, MG, Brazil & Solanum cernum \\
\hline 19 & RWB551 & $\mathrm{S}$ & Juiz de Fora, MG, Brazil & Solanum lycocarpum \\
\hline
\end{tabular}

${ }^{1}$ Isolate origin: (MG) Minas Gerais state, (BA) Bahia state, (PA) Pará state, (AM) Amazonas state; the states of AM and PA are located in the Brazilian Amazon; (NA) Napo Province, (RI) Los Rios Province in Coastral.

${ }^{2}$ The isolates of M. perniciosa examined in this study were kindly given by Profa. Dra. Maricília C. C. Arruda from the Federal University of Brasilia, Brasilia, Distrito Federal/Brazil, Prof. Dr. Gonçalo A. G. Pereira from the State University of Campinas, Campinas, São Paulo/Brazil, Prof. Dr. Mário Lúcio Vilela de Resende from Federal University of Lavras, Lavras, Minas Gerais/Brazil, Dr. Alan W. V. Pomella from Almirante Cacau, Itajuipé, Bahia/Brazil and by Prof. Dr. Robert W. Barreto from the Federal University of Viçosa, Viçosa, Minas Gerais/Brazil. All isolates used in this study can be found in a collection maintained at the Laboratório de Genética de Microorganismo at Federal University of Viçosa, ${ }^{3}$ Isolate of reference used in the "Witches' broom Genome" Project (Mondego et al., 2008).

(Promega), $0.5 \mu \mathrm{M}$ of each primer, $100 \mu \mathrm{M}$ of dNTP, 50 $\mathrm{mM}$ of $\mathrm{KCl}, 2.5 \mathrm{mM}$ of $\mathrm{MgCl}_{2}$ (Promega) and $1 \mathrm{U}$ of $\mathrm{Taq}$ DNA polymerase (Promega). The amplifications were done in a thermocycler PTC-100 (MJ Research, Inc.) programmed for 40 cycles, each cycle composed of an initial step of denaturation at $94^{\circ} \mathrm{C}$ for $1 \mathrm{~min}$, followed by $1 \mathrm{~min}$ at $55^{\circ} \mathrm{C}$ for the primer annealing, $70 \mathrm{~s}$ for extension at $72^{\circ} \mathrm{C}$ and a final extension at $72^{\circ} \mathrm{C}$ for $7 \mathrm{~min}$. The negative control (no DNA template) was used to test for the presence of a nonspecific reaction. The products of amplification were analyzed by gel electrophoresis in a $1.5 \%(\mathrm{w} / \mathrm{v})$ agarose gel stained with ethidium bromide. The visualization and image recording were done with the photo documentation system Eagle Eye II (Stratagene).

\section{Cloning, sequencing and sequence analysis}

An aliquot of the DNA product amplified from the isolate $\mathrm{CP} 02$ with the MiMp1 and MiMp2 primers was cloned by the vector TOPO ${ }^{\circledR}$ (TOPO TA Cloning ${ }^{\circledR}$ Fiveminute cloning of Taq polymerase-amplified PCR products, Invitrogen Life Technologies) according to the manufacturer instructions. The DNA sequencing was done using the BigDye ${ }^{\circledR}$ Terminator v.3.1 Cycle Sequencing kit (Applied Biosystems) in ABI Prism 3700 DNA Sequencer (Applied Biossytems). The resulting DNA sequence was used to search the National Center for Biotechnology Information (NCBI) database using the BLAST service network (Altschul et al., 1997). Further DNA and deduced protein sequence analysis were carried out using the Clustal W program for multiple alignments (Thompson et al., 1994). The sequences used in the alignment and phylogenetic analysis were obtained from the GenBank and listed in table 2. The alignment was done using the software MEGA4 (Tamura et al., 2007), the tree was built using the neighbor-joining method, p-distance model (Saitou \& Nei, 1987), with bootstrap values with 1000 replicates.

\section{Southern blot}

An aliquot of approximately $3 \mu \mathrm{g}$ of total DNA was digested with the restriction enzymes EcoRI (Stratagene) and EcoRV (Promega), used because these restriction sites are not present in the DNA fragments used as a probe. The DNA fragments were separated in a $0.8 \%(\mathrm{w} / \mathrm{t})$ agarose gel and transferred to a Duralon-UVTM membrane (Stratagene) according to the standard protocol (Sambrook et al., 1989). Hybridization was carried out at $65^{\circ} \mathrm{C}$, and a DNA fragment of $911 \mathrm{bp}$ was used as probe relative to the Mico sequence. The DNA fragment used as a probe was purified using the GFX ${ }^{\mathrm{TM}}$ PCR DNA and Gel Band Purification kit (Amersham Biosciences) and $200 \mathrm{ng}$ of DNA were labeled with $\left[\alpha-{ }^{32} \mathrm{P}\right] \mathrm{dCTP}$ with the Random Prime IT II Labeling kit (Stratagene), according to the manufacturer's instructions. 
The distribution of a transposase sequence in Moniliophthora perniciosa confirms...

TABLE 2 - Sequences used in the alignment and phylogenetic analysis

\begin{tabular}{lll}
\hline \hline Sequence & \multicolumn{1}{c}{ Organism } & GenBank access numbers \\
\hline Mico & Moniliophthora perniciosa & JN030398 \\
Hypothetical protein mRNA & Moniliophthora perniciosa & XM_002396440.1 \\
Putative transposase & Phaeosphaeria nodorum & CAD32687.1 \\
pogoputative transposable element & Penicillium marneffei & XP_002147352.1 \\
pogoputative transposable element & Talaromyces stipitatus & XP_002482644.1 \\
Hypothetical protein & Sclerotinia sclerotiorum & XP_001587829.1 \\
Transposase Tan1 & Aspergillus niger & CBF73878.1 \\
Transposase Tct Mariner & Penicillium marneffei & S80872.1 \\
Transposase Tcl-Mariner & Aspergillus niger & AAC49623.1 \\
Transposase Tcl-Mariner & Aspergillus awamori & AAV32822.1 \\
Transposase $h$ AT & Zea mays & XM_002391032.1 \\
Transposase $h$ AT & Moniliophthora perniciosa & XP2831038.1 \\
Transposase Merlin & Pongo abelii & NP_7366092 \\
Transposase piggyBac & Homo sapiens & BAF82024.1 \\
Transposase piggyBac & Xenopus tropicalis & AAM76341.1 \\
Transposase piggyBac & Daphnia pulicaria & ABB83644.1 \\
Transposase PIF/Harbinger & Daucus carota & ABW98496.1 \\
PIF/Harbinger & Moniliophthora perniciosa & XP_002709124.1 \\
PIF/Harbinger & Oryctolagus cuniculus & AAH36925.1 \\
PIF/Harbinger & Homo sapiens & AAH78390.1 \\
PIF/Harbinger & Danio rerio &
\end{tabular}

The membranes were subjected to autoradiography with Kodak X-OTMATIC K film for $30 \mathrm{~min}$.

\section{Southern blot data analysis}

The data acquired by the Southern blot analysis was used to estimate the genetic distance between different isolates of M. perniciosa. The autoradiographs were analyzed and the values 0 and 1 refer to the absence or presence of the Mico sequence. The calculation of the genetic distance matrix was done using the Jaccard coefficient and the grouping of isolates was done by the UPGMA method, with the software GENES STATISTICA 5.0 for Windows (Cruz, 1997).

\section{RESULTS}

\section{Analysis of the Mico sequence}

Comparative analysis of the Mico sequence (911 bp) with sequences submitted to the NCBI database through BLASTn indicated high similarity $(81 \%$ coverage, $100 \%$ identity and E-value 0.0 ) to a cDNA sequence of M. perniciosa (XM 002396440.1). The alignment of the genomic and cDNA sequences through the BLAST allowed the identification of two introns in the amplicon. These introns show consensus 5'(GT) and 3'(PyAG) sequences (Figure 1A), that are commons to introns of filamentous fungi (Gurr et al., 1987). The removal of these introns followed by analysis through the BLASTx enabled the identification of a 264 amino acid sequence (Figure 1B). This amino acid sequence, when analyzed, included a DDE motif that usually has three acidic residues, two aspartic and one glutamic acid, though in some cases, another aspartic acid (DD[E/D]) replaces the glutamic acid. However, in the Mico sequence analyzed the last residue from the DDE motif was not found (Figure 2), indicating that these putative element copies have lost their capacity to transpose. These inactive copies are suitable as genetic markers.

The polypeptide chain encoded by the Mico sequence showed identity with transposases isolated from other pathogenic fungi: Schizophyllum commune (XP_003028073.1, 42\% coverage, 56\% identity, E-value 5e-34), Ajellomyces capsulatus (XP_001540201.1, 78\% coverage, 36\% identity, E-value 4e-28) and Phaeosphaeria nodorum (CAD32687.1, 89\% coverage, 35\% identity, E-value 7e-34). It also showed identity to TEs described in filamentous fungi: Fot5 isolated from F. oxysporum f. sp. lycopersici (CAE55867.1, 87\% coverage, 33\% identity, E-value 6e-28), pogo described in Talaromyces stipitatus (XP_002488844.1, 78\% coverage, 34\% identity, E-value 6e-28) and in Penicillium marneffei (XP_002147352.1, $92 \%$ coverage, $32 \%$ identity, E-value $7 \mathrm{e}-29)$. The latter are related to TEs that belong to the Tc1-Mariner superfamily, indicating that the Mico sequence was probably amplified by a putative element of this superfamily in the genome of M. perniciosa. The phylogenetic analysis of the transposase codified by the Mico sequence confirmed that Mico clustered with other transposases of the Tc1-Mariner superfamily (Figure 3).

\section{Detection and distribution of Mico sequence}

The detection and distribution analysis of the Mico sequence by PCR showed the presence of amplification products in nine isolates from $C$-biotype, two isolates from 
M.D.C. Ignacchiti et al.

A)

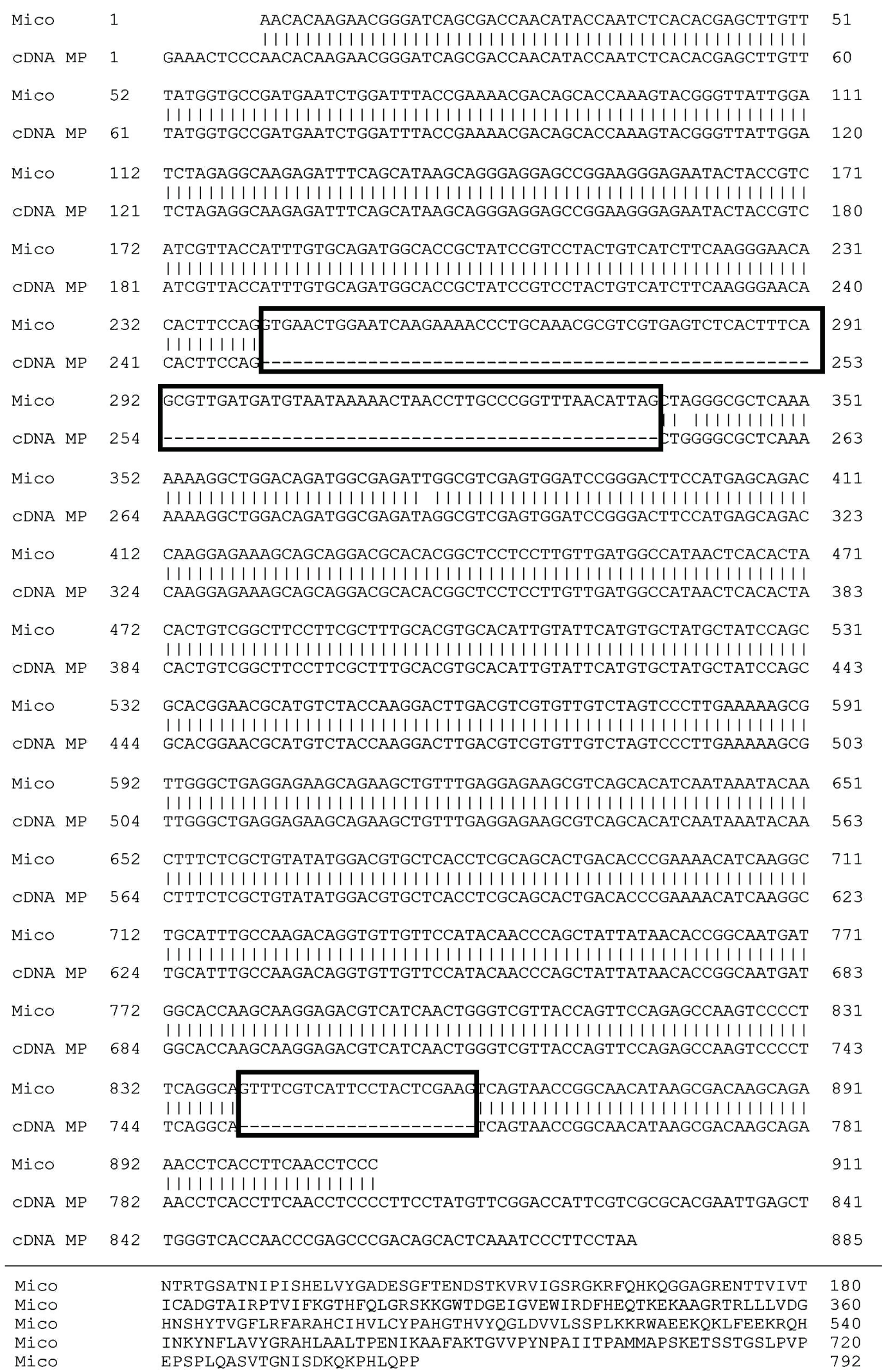

FIGURE 1 - A. Nucleotide sequence alignment. Mico - nucleotide sequence obtained from sequencing of the amplification product of the primers MiMP1 and MiMP2 in the CP02 isolate; cDNA MP - nucleotide sequence from cDNA of M. perniciosa (XM_002396440.1). Box indicates the location of introns, the vertical bar (|) indicates the presence of the same base among the sequences and the horizontal dash (-) indicates the absence of nucleotide; B. Deduced partial amino acid sequence from M. perniciosa encoded by the Mico sequence. 


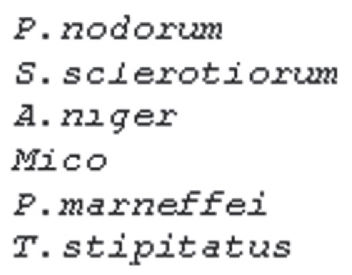

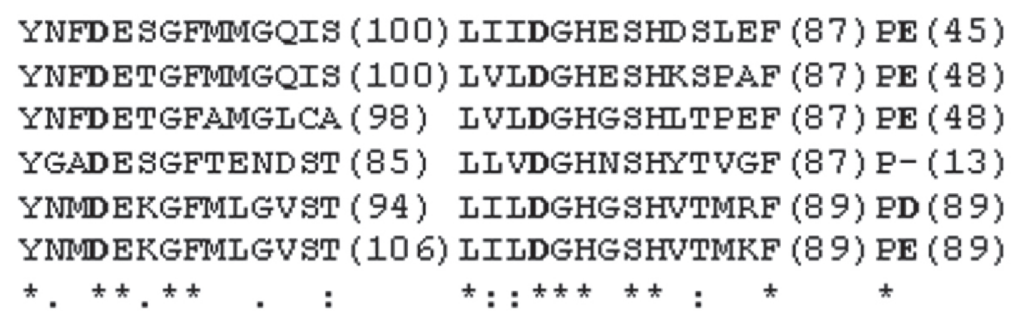

FIGURE 2 - Deduced partial amino acid sequence from M. perniciosa encoded by the Mico sequence aligned with homologous polypeptides from different filamentous fungi. Amino acid residues that constitute the motif DDE are in bold. The presence of a dot (.) represents amino acids with low similarity; a colon (:), amino acids with high similarity; an asterisk (*), identical amino acids; a dash (-), absence of amino acids and numbers inside brackets represent the number of omitted amino acids in the alignment. Identification of the sequences listed in the Table 2.
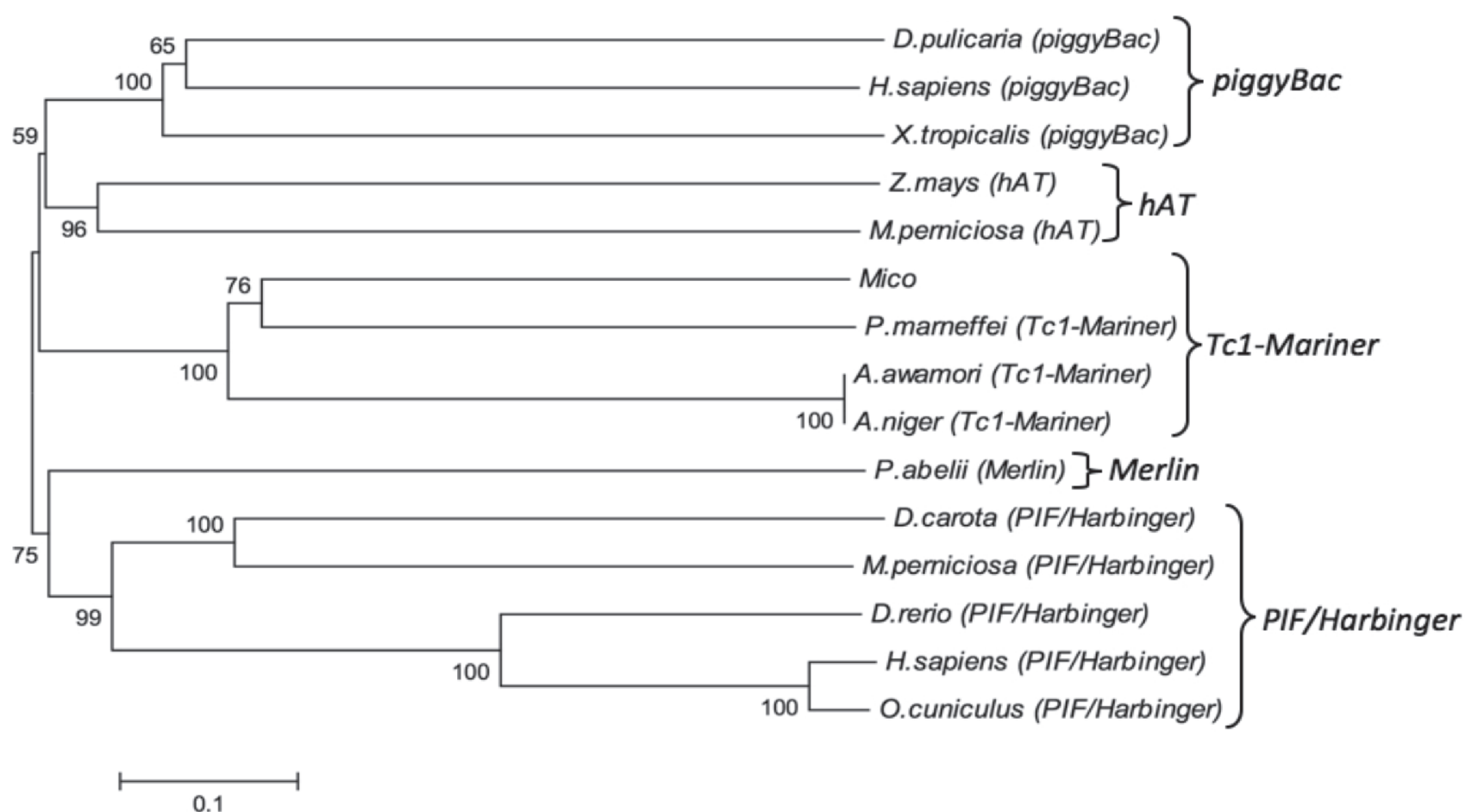

FIGURE 3 - Phylogenetic tree showing the links among the Mico sequence with transposases of other organisms. The tree was built using the neighbor-joining method, p-distance model. The numbers above and below each node indicate the percentage of times in which each branch appeared in a bootstrap analysis with 1,000 replicates. The superfamily of each sequence used in the analysis is between brackets. The clades from the major superfamilies with high bootstrap values $(>50)$ are shown. Identification of sequences listed in the Table 2 .

$L$-biotype and two isolates from $S$-biotype, of a total of 19 isolates analyzed (Figure 4). Only the amplified fragments of isolates from $C$-biotype and the isolate LA17 ( $L$-biotype) showed the expected size (911 bp). The isolate SCL4, from $L$-biotype, showed an amplified fragment smaller than expected, while for the isolates FA609 and RWB511, both $S$-biotype, the existence of an amplified product larger than expected was observed.

The analysis of distribution of the Mico sequence by Southern blot showed signals in all the isolates of $C$-biotype, for both enzymes used, and differences in the intensity and size of these signals in the isolates were detected (Figure 5A and 5C). In the isolates from $L$ and $S$-biotypes only the isolate LEP1 showed a hybridization signal (Figure 5B and 5D). The absence of signal in the other isolates may indicate the absence of the Mico sequence, or be related to the presence of altered and/or degenerated copies that have undergone changes over the evolutionary history.

A distinct distribution of the Mico sequence was observed for the different isolates. A fragment with an estimated size of $5.5 \mathrm{~kb}$ is present is all isolates of the 

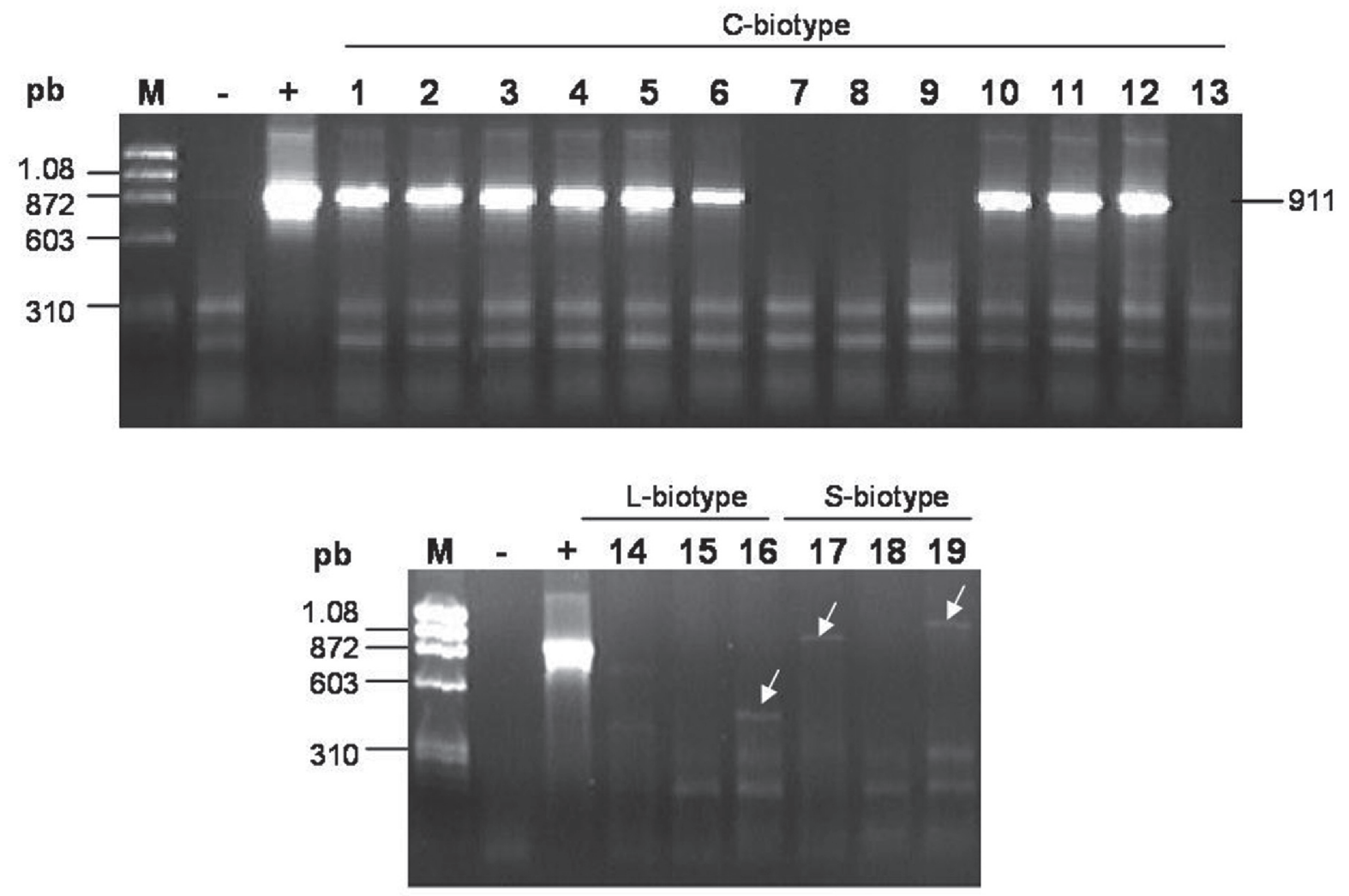

FIGURE 4 - PCR products (911 pb) obtained from the primer pair MiMp1 and MiMp2 in the isolates of M. perniciosa. Arrows indicate amplification fragments with a size different from expected. (M) Molecular size marker фX174 HaeIII (DNA фX174 digested with HaeIII); (-) negative control (mix of reaction without the DNA template); $(+)$ positive control (plasmid containing the 911 bp fragment cloned); numbers 1-19 indicate the isolates of M. perniciosa listed in the Table 1.

$C$-biotype (Figure 5A) and only in one isolate of the $L$-biotype (Figure $5 \mathrm{~B}$ ). However, among the isolates from $C$-biotype, fragments of 1.8, 9.4 and $12.1 \mathrm{~kb}$ were only shown in the Santo Amaro, ESJOH1, FA551, FA42 and SABA isolates (Figure 5A), implying the presence of at least two hybridization profiles for this biotype. The distribution profile of the Mico sequence in the analysis with EcoRV, for isolates from $C$-biotype, revealed a polymorphic fragment of $6.5 \mathrm{~kb}$ only present in the Santo Amaro, ESJOH1, FA551 and SABA isolates (Figure 5C), confirming the existence of two hybridization profiles among the $C$-biotype isolates.

\section{Analysis of the Mico distribution profile}

The distribution profile of the Mico sequence was used to calculate the genetic distance matrix between the isolates and enabled the construction of a tree diagram. The analysis of this diagram confirmed the occurrence of two fingerprinting profiles of this sequence in the isolates from $C$-biotype from the Bahia state (Figure 6). Although the grouping is related to the different geographic regions from where the fungus was isolated, some isolates from geographically separated groups could be grouped together. This is the case for the SABA and Santo Amaro isolates, from
Bahia, and two isolates from the Amazon region, ESHOJ1 and FA551, which showed similar hybridization profiles.

\section{DISCUSSION}

The use of internal sequences of TEs as molecular markers to delineate population profiles in phytopathogenic fungi has been reported in several studies (Chiocchetti et al., 1999; Harmon et al., 2003; Jiménez-Gasco \& JiménezDiaz, 2003). The present study shows the distribution of a sequence phylogenetically related to the transposases of putative elements of the Tc1-Mariner superfamily in isolates of the phytopathogenic fungus $M$. perniciosa and correlates its distribution to the epidemiological profile of the Witches' broom disease in the Bahia state of Brazil.

The transposase catalytic activity in the TE superfamily Tcl/mariner is associated with the presence of the $\mathrm{DD}[\mathrm{E} / \mathrm{D}]$ motif. This motif is characterized by the presence of two aspartic acid residues (D) and one glutamic acid (E) or aspartic acid (D) residue (Nesmelova \& Hackett, 2010). In elements of the Fot1 family (Tc1-Mariner superfamily), residue $\mathrm{E}$ has a conserved substitution to residue D (Nyyssönen et al., 1996). All DD[E/D]- 
A)

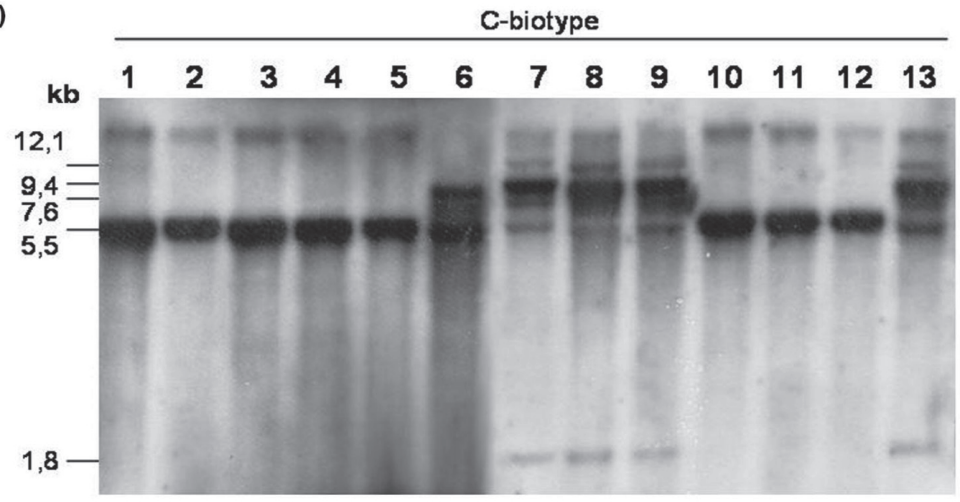

C)
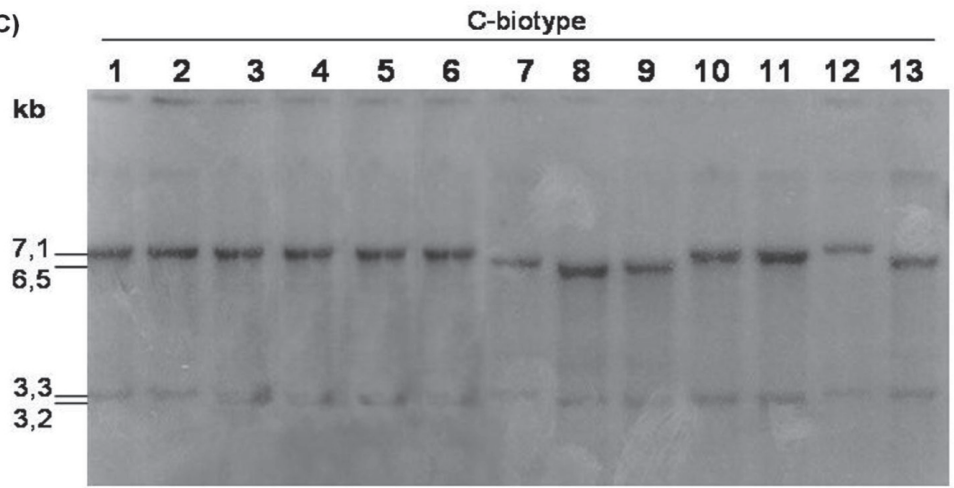

B)

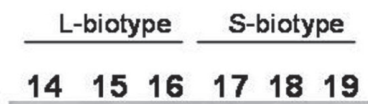

kb

7,6

5,5
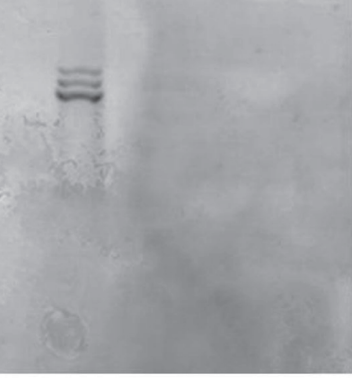

D)

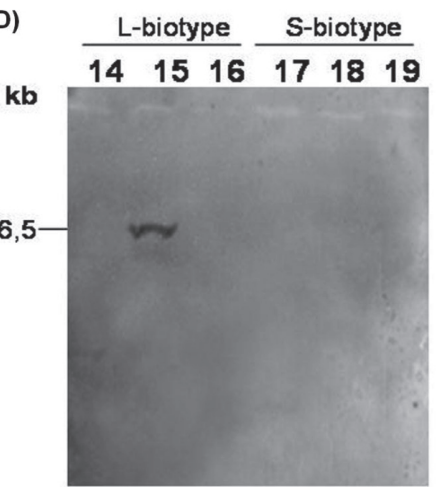

FIGURE 5 - Southern blot analysis of total DNA from $M$. perniciosa isolates using the plasmid containing the Mico sequence as probe. A-B. hybridization profile of total DNA cleaved with the restriction enzyme EcoRI; C-D. hybridization profile of total DNA cleaved with the restriction enzyme EcoRV. Numbers 1-19 indicate isolates of M. perniciosa listed in Table 1. Molecular size was estimated based on the molecular size marker $\lambda$ HindIII.

\section{Genetic Divergence (\%)}

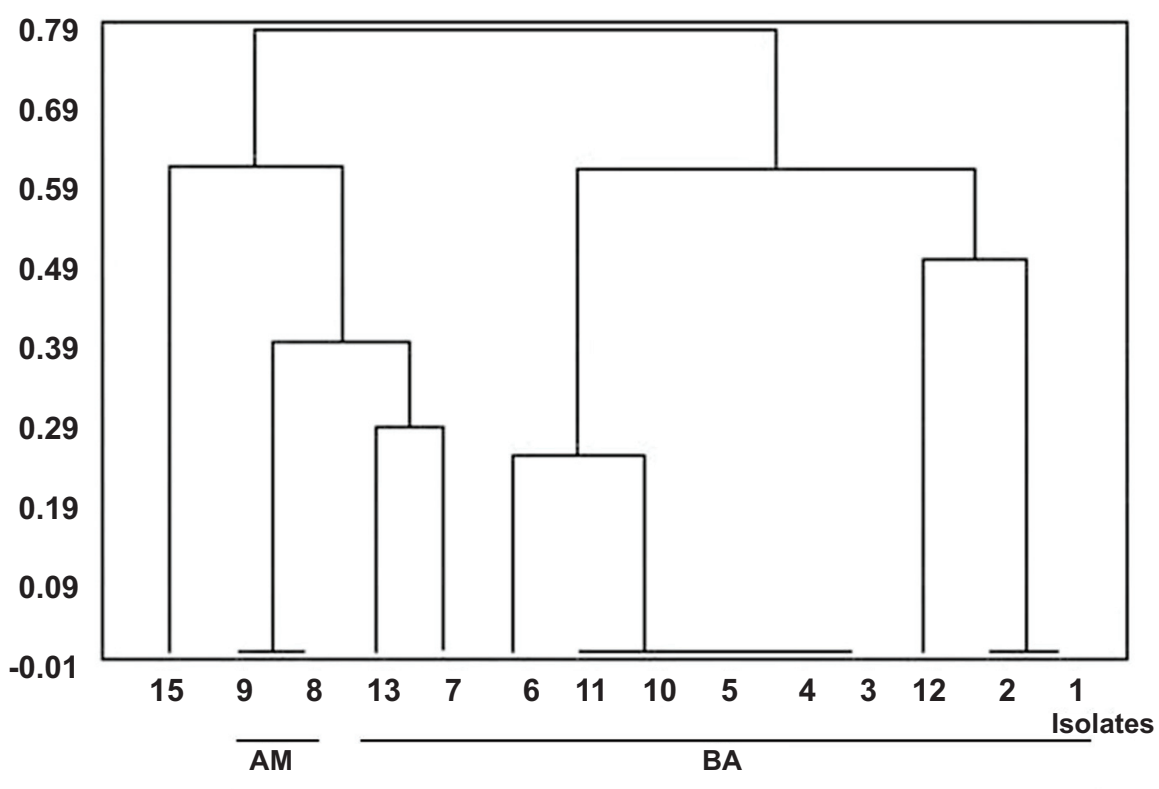

L-biotype
FIGURE 6 - Tree diagram from the hierarchical grouping analysis by the UPGMA method, based on the arithmetic complement of the Jaccard index to the Mico sequence. (AM) isolates collected in the Brazilian Amazon region; (BA) isolates collected in the Bahia state. Numbers 1-19 indicate isolates of $M$. perniciosa listed in Table 1. 
transposases catalyze the mobilization of DNA segments using a mechanism that begins with the hydrolysis of phosphodiester bonds at the termini of the TIR (Terminal Inverted Repeats) of the transposon DNA, which leads to the formation of free $3^{\prime}-\mathrm{OH}$ groups. The $3^{\prime}-\mathrm{OH}$ groups are protected by the transposase until they are joined to the target DNA via a transesterification reaction, which is also catalyzed by the transposase (Nesmelova \& Hackett, 2010).

The analysis of the codified polypeptide chain by the Mico sequence showed the presence of the non-intact $\mathrm{DD}[\mathrm{E} / \mathrm{D}]$ motif. This fact can be probably due to the number of mutations in the different copies of Mico and is therefore probably inactive. However, according to Nesmelova \& Hackett (2010), the structure of DD[E/D]-transposase can show unexpected variations that reflect the different ways by which the $\mathrm{DD}[\mathrm{E} / \mathrm{D}]$-transposase recognizes the transposon, assembles a synaptic complex, and completes the cleavage and binding that results in transposition.

In assessing the distribution of the Mico sequence by PCR and Southern blot techniques, it was observed that in some isolates this sequence is only demonstrated by Southern technique. This is the case of isolates Santo Amaro, ESJOH1, FA551, SABA, LEP1, which did not show an amplification product when the primers MiMp1 and MiMp2 were used. The fact that it was not possible to detect Mico in these isolates by PCR does not eliminate the possibility of its presence in this fungus genome, being possible the occurrence of alterations in the primer annealing sites, which would then cause variations in the sequences that lead to the non-alignment of the primers. However, the presence of sequences like Mico was found in these isolates by Southern analysis, and hybridization profiles differ from other isolates from $C$-biotype. This result suggests the presence of internal alterations in the Mico sequence, which is in agreement with the presence of subfamilies of this element in the genome of M. perniciosa. A similar result was described by Zanotti et al. (2005) when the impala element (Tc1-Mariner superfamily) distribution in different isolates of $F$. oxysporum was analyzed. In addition, in the study performed by Hua-Van et al. (2001), the isolates of $F$. oxysporum that showed no amplification product with primers specific to the impala element, the Southern blot technique confirmed the presence of this element and sequencing showed that these were copies of other subfamilies.

The presence of bands with a low hybridization signal and a lower intensity of amplification products for the Mico sequence suggest the occurrence of a low copy number, and also indicate the occurrence of subfamilies of this element in the genome of M. perniciosa. To confirm the occurrence of a subfamily this putative element in the genome of M. perniciosa, other copies of the Mico sequence must be sequenced. For the impala element, Southern blot analysis of 32 strains of $F$. oxysporum, belonging to different formae especialis, revealed the presence of subfamilies of this element. These subfamilies are represented by a low copy number, suggesting that the element is not active or that selection eliminates additional copies (Hua-Van et al., 2001).

Differences in the amplification product size and the hybridization signals to the Mico sequence may be the result of rearrangement or recombination events involving dispersed copies in the genome, internal alterations in the sequence, presence of truncated copies and even insertions of other TEs. In M. grisea, the analysis of the hybridization profile of the Pot 2 element, a member of the Tc1-Mariner superfamily, showed a copy number polymorphism among the different isolates, and the analysis of the sequence of one of these polymorphic copies showed an insertion of an element similar to the retrotransposon SINE (Kachroo et al., 1994). The presence of truncated copies of the impala element in the strain of F. oxysporum (FOM24) was described by Hua-Van et al. (1998); according to these authors, the occurrence of truncated copies may be considered old insertions in which occurred an accumulation of mutations.

The occurrence of a hybridization signal of constant size (estimated at $5.5 \mathrm{~kb}$ ) in the Southern analysis in all isolates from $C$-biotype and in only one isolate from $L$-biotype suggests that the Mico sequence probably is an "old resident" of the $M$. perniciosa genome and that was lost in the other isolates from $S$ and $L$-biotypes. Another hypothesis is that the copies of the Mico sequence in the isolates from $S$-biotype (FA609, RWB500, RWB551) and $L$ (LA17 e SCL4) have undergone changes during evolution, making the identification by Southern difficult. Therefore, the hybridization profile, as shown by the Mico sequence, suggests that this sequence represents a non-active putative element that was acquired by a common ancestor before the biotype divergence and was inherited vertically by the descendants. The analysis of the polypeptide chain encoded by the Mico sequence showed the presence of the non-intact $\mathrm{DD}[\mathrm{E} / \mathrm{D}]$ motif, strengthening the hypothesis that non-active putative element. The presence of copies with estimated sizes of 6.5 and $7.6 \mathrm{~kb}$ in the Southern analysis, where the DNA was cut with $E c o$ RV and EcoRI, respectively, for the Santo Amaro, ESJOH1, FA551, SABA and LEP1 isolates, supports the hypothesis of acquisition by a common ancestor and vertical transfer inheritance. In the impala element in F. oxysporum, the presence of copies of a constant size in related lineages suggests that this element was inserted in a common ancestor (Hua-Van et al., 2001).

The analysis of the tree diagram generated from the hybridization profile of the Mico sequence in the different isolates of M. perniciosa reveals two distribution profiles of this sequence for the isolates of $C$-biotype from the Bahia state, with one similar to the profile shown by the isolates from the Brazilian Amazon region. Thus, it was possible to group the isolates from $C$-biotype from the Bahia state with the isolates from the Brazilian Amazon region. Arruda et al. (2003b) also showed that some isolates of M. perniciosa from the Bahia state are genetically related to isolates 
The distribution of a transposase sequence in Moniliophthora perniciosa confirms...

from Belém-PA, Brazilian Amazon region. In a parallel study, Arruda et al. (2003a) has shown that IGS sequences of isolates from southern Bahia are highly similar to sequences of isolates from the Amazon region. Ploetz et al. (2005), through the use of AFLP markers, demonstrated the grouping of isolates derived from Bahia with isolates from the Amazon region.

The molecular data obtained in the present study suggests the existence of two independent foci of the disease in the state of Bahia (Brazil), but also gives credence to the hypothesis that the appearance of Witches' broom disease in southern Bahia may have been caused by the gene movement of isolates of $M$. perniciosa, brought in seedlings of T. cacao from the Brazilian Amazon region. The presence of two independent preliminary foci of Witches' broom in southern Bahia has previously been proposed by Andebrhan et al. (1999) and Rincones et al. (2003; 2006). According to Andebrhan et al. (1999), the geographic distribution of the genetic groups in Bahia and the fact that M. perniciosa $C$-biotype is homothallic suggest the existence of two independent points of introduction of this pathogen into the cocoa-growing region of Bahia. Pereira et al. (2007) showed two different distribution profiles of a RT-like (reverse transcription) sequence in isolates from $C$-biotype collected in the Bahia. In conclusion, these studies correlate the occurrence of these two genotypes with two independent introductions of Witches' broom disease in the southern region of the Bahia state.

Thus, the distribution profile of the Mico sequence in the genome of different isolates of M. perniciosa provides evidence of two different genotypes of the phytopathogen in the Bahia state. These results contribute significantly to the identification of the introductory movement and the spread of the Witches' broom disease in the Bahia state, Brazil.

\section{ACKNOWLEDGEMENTS}

We are grateful for the financial support from the Brazilian funding agencies Coordenação de Aperfeiçoamento de Pessoal de Nível Superior - CAPES, Conselho Nacional de Desenvolvimento Científico e Tecnológico - CNPq, Fundação de Amparo à Pesquisa do Estado de São Paulo - FAPESP and Secretaria de Agricultura do Estado da Bahia - SEAGRI. We also are grateful to Dr. Jorge Fernando Pereira for his helpful advice in this study.

\section{REFERENCES}

Altschul SF, Madden TL, Schaffer AA, Zhang J, Zhang Z, Miller W, Lipman DJ (1997) Gapped BLAST and PSI_BLAST: a new generation of protein database search programs. Nucleic Acids Research 25:3389-3402.

Andebrhan T, Furtek DB (1999) Molecular fingerprinting suggests two primary outbreaks of witches' broom disease (Crinipellis perniciosa) of Theobrama cacao in Bahia, Brazil. European
Journal of Plant Pathology 105:167-175.

Arkhipova IR, Pyatkov KI, Meselson M, Evgen'ev MB (2003) Retroelements containing introns in diverse invertebrate taxa. Nature Genetics 33:123-124.

Arruda MCC, Ferreira MASV, Miller RNG, Resende ML, Felipe MS (2003a) Nuclear and mitochondrial rDNA variability in Crinipellis perniciosa from different geographic origins and hosts. Mycological Research 107:25-37.

Arruda MCC, Miller RNG, Ferreira MASV, Felipe MS (2003b) Comparison of Crinipellis perniciosa isolates from Brazil by ERIC repetitive element sequence-based PCR genomic fingerprinting. Plant Pathology 52:236-244.

Bastos CN, Evans HC (1985) A new pathotype of Crinipellis perniciosa (witches' broom disease) on solanaceous hosts. Plant Pathology 34:306-312.

Bastos CN, Anderbhran T, Almeida LC (1988) Comparação morfológica de isolados de Crinipellis perniciosa. Fitopatologia Brasileira 13:202-205.

Bouvet FB, Jacobi V, Plourde KV, Bernier L (2008) Stress-induced mobility of OPHO1 and OPHO2, DNA transposons of the Dutch elm disease fungi. Fungal Genetics and Biology 45:565-578.

Chadha S, Gopalakrishna T (2005) Retrotransposon-microsatellite amplified polymorphism (REMAP) markers for genetic diversity assessment of the rice blast pathogen (Magnaporthe Grisea). Genome 48:943-945.

Chiocchetti A, Bernardo I, Daboussi MJ, Garibaldi A, Gullino ML, Langin T, Migheli Q (1999) Detection of Fusarium oxysporum $f$. $s p$. dianthi in carnation tissue by PCR amplification of transposon insertions. Phytopathology 89:1169-1175.

Crouch JA, Glasheen BM, Giunta MA, Clarke BB, Hillman BI (2008) The evolution of transposon repeat-induced point mutation in the genome of Colletotrichum cereale: reconciling sex, recombination and homoplasy in an "asexual" pathogen. Fungal Genetics and Biology 45:190-206.

Cruz CD (1997) Programa Genes - Aplicativo computacional em genética e estatística. v.1. Viçosa MG. Editora UFV.

Daboussi MJ (1997) Fungal transposable elements and genome evolution. Genetica 100:253-260.

Daboussi MJ, Capy P (2003) Transposable elements in filamentous fungi. Annual Review of Microbiology 53:275-299.

Evans HC (1978) Witches' broom disease of cocoa (Crinipellis perniciosa) in Ecuador. Annals of Applied Biology 89:185-192.

Gurr SJ, Unkles SE, Kinghorn JR (1987) The structure and organization of nuclear genes of filamentous fungi. In: Kinghorn JR (Ed) Gene Structure in Eukaryotic Microbes. IRL Press, Oxford UK. pp. 93-139.

Harmon PF, Dunkle LD, Latin R (2003) A rapid PCR-based method for the detection of Magnaporthe oryzae from infected perennial ryegrass. Plant Disease 87:1072-1076.

Hedger JN, Pickering V, Arangundi J (1987) Variability of population of the witches' broom disease of cocoa (Crinipellis perniciosa). Transactions of the British Mycological Society 88:533-545.

Hua-Van A, Héricourt P, Capy P, Dadoussi MJ, Langin T (1998) Tree highly divergent subfamilies of the impala transposable 
element coexist in the genome of fungus Fusarium oxysporum. Molecular and General Genetics 259:354-362.

Hua-Van A, Langin T, Dadoussi MJ (2001) Evolutionary history of the impala transposon in Fusarium oxysporum. Molecular Biology and Evolution 18:1959-1969.

Jimenez-Gasco MM, Jimenez-Diaz RM (2003) Development of a specific PCR-based assay for the identification of Fusarium oxysporum $\mathrm{f}$. sp. ciceris and its pathogenic races $0,1 \mathrm{~A}, 5$, and 6. Phytopathology 93:200-209.

Kachroo P, Leong SA, Chatoo BB (1994) Pot2, an inverted repeat transposon from rice blast, Magnaporthe grisea. Molecular and General Genetics 245:339-348.

Meinhardt LW, Rincones J, Bailey BA, Aime MC, Griffith GW, Zhang D, Pereira GAG (2008) Moniliophthora perniciosa, the causal agent of witches' broom disease of cacao: what's new from this old foe? Molecular Plant Pathology 9:577-588.

Mondego JM, Carazzolle MF, Costa GG, Formighieri EF, Parizzi LP, Rincones J, Cotomacci C, Carraro DM, Cunha AF, Carrer H, Vidal RO, Estrela RC, García O, Thomazella DP, de Oliveira BV, Pires AB, Rio MC, Araújo MR, de Moraes MH, Castro LA, Gramacho KP, Gonçalves MS, Neto JP, Neto AG, Barbosa LV, Guiltinan MJ, Bailey BA, Meinhardt LW, Cascardo JC, Pereira GA. (2008) A genome survey of Moniliophthora perniciosa gives new insights into Witches' Broom Disease of cacao". BioMed Central Genomics 9:1-25.

Nesmelova IV, Hackett PB (2010) DDE transposases: Structural similarity and diversity. Advanced Drug Delivery Reviews 62:1187-1195.

Nyyssönen E, Amutan M, Enfield L (1996) The transposable element Tan 1 of Aspergillus niger var. awamori, a new member of the Fot1 family. Molecular and General Genetics 253:5056.

Pasquali M, Dematheis F, Gullino ML, Garibaldi A (2007) Identification of race 1 of Fusarium oxysporum f. sp.lactucae on lettuce by inter-retrotransposon sequence-characterized amplified region technique. Phytopathology 97:987-996.

Pereira JF, Ignacchiti MDC, Araújo EF, Brommonschenkel SH, Cascardo JCM, Pereira GAG, Queiroz MV (2007) PCR Amplification and sequence analyses of reverse transcriptaselike genes in Crinipellis perniciosa isolates. Fitopatologia Brasileira 32:373-380.

Pereira JL, Ram A, Figuereido JM, De Almeida LCC (1990) The first occurrence of witches' broom disease in the principal cocoa-growing region of Brazil. Tropical Agriculture 67:188189.

Ploetz RC, Schnell RJ, Ying Z, Zheng QI, Olano CT, Juan C, Motamayor JC, Johnson ES (2005) Analysis of molecular diversity in Crinipellis perniciosa with AFLP markers. European Journal of Plant Pathology 111:317-326.

Resende ML, Nojosa GBA, Aguilar MG, Silva LHCP, Niella GR, Carvalho GA, Giovanni GR, Castro RM (2000) Crinipellis perniciosa proveniente de um novo hospedeiro Heteropterys acutifólia, é patogênico ao cacaueiro. Fitopatologia Brasileira 25:88-91.
Rincones J, Meinhardt LW, Vidal BC, Pereira GAG (2003) Electrophoretic karyotype analysis of Crinipellis perniciosa, the causal agent of witches' broom disease of Theobroma cacao. Mycological Research 107:452-458.

Rincones J, Mazotti GD, Griffith GW, Pomela A, Figueira A, Leal GA, Queiroz MV, Pereira JF, Azevedo RA, Pereira GAG, Meinhardt LW (2006) Genetic variability and chromosomelength polymorphisms of the witches' broom pathogen Crinipellis perniciosa from various plant hosts in South America. Mycological Research 110:821-832.

Saitou N, Nei M (1987) The neighbor-joining method: a new method for reconstructing phylogenetic trees. Molecular Biology and Evolution 4:406-425.

Sambrook J, Fritsch EF, Maniatis T (1989) Molecular cloning: a laboratory manual. $2^{\text {th }}$ Ed. Cold Spring Harbor, New York. Cold Spring Harbor Laboratory Press.

Speacht CA, Dirusso CC, Novotny CP, Ullrich RCA (1982) A method for extracting high molecular weight deoxyribonucleic acid from fungi. Analytical Biochemistry 199:158-163.

Tamura K, Dudley J, Nei M, Kumar S (2007) MEGA4: Molecular evolutionary genetics analysis (MEGA) software version 4.0. Molecular Biology and Evolution 24:1596-1599.

Taylor EJ, Konstantinova P, Leigh F, Bates JA, Lee D (2004) Gypsy-like retrotransposons in Pyrennophora: an abundant and informative class of molecular markers. Genome 47:519-525.

Thompson JD, Higgins DG, Gibson TJ (1994) CLUSTAL W: improving the sensibility of progressive multiple sequence alignment through sequence weighting, position specific gap penalties and weight matrix choice. Nucleic Acids Research 22:4673-4680.

Viana Junior CAC (2001) Compatibilidade somática e patogenicidade de Crinipellis sp. Dissertação de Mestrado. Universidade Federal de Lavras, Lavras MG.

Wicker T, Sabot F, Huan-Van A, Bennetzen JL, Capy P, Chalhoub B, Flavell A, Leroy P, Morgante M, Panaud O, Paux E, Sanmiguel P, Schulman AK (2007) A unified classification system for eukaryotic transposable. Nature Reviews Genetics 8:973-982.

White TJ, Bruns T, Lee S, Taylor JW (1990) Amplification and direct sequencing of fungal ribosomal RNA genes for phylogenetics. In: Innis MA, Gelfand DH, Sninsky JJ, White TJ (Eds.) PCR Protocols: A Guide to Methods and Applications1990. New York N.Y., Academic Press. pp. 315-322.

Zanotti MGS, Santos JK, Reis KCP, Araújo EF, Dhingra OD, Queiroz MV (2005) Distribution of the transposable element impala in Fusarium oxysporum isolates pathogenic and nonpathogenic to common bean. Fitopatologia Brasileira 30:244-249.

\section{INTERNET RESOURCES}

"Witches' broom Genome" project database: http://www.lge. ibi.unicamp.br/vassoura

NCBI database, BLAST tool: http://blast.ncbi.nlm.nih.gov/ Blast.cgi 